\title{
A study on the aerosol extinction-to-backscatter ratio with combination of micro-pulse LIDAR and MODIS over Hong Kong
}

\author{
Q. S. He ${ }^{1,3}$, C. C. $\mathbf{L i}^{1}$, J. T. Mao ${ }^{1}$, A. K. H. Lau $^{2}$, and P. R. $\mathbf{L i}^{4}$ \\ ${ }^{1}$ Department of Atmospheric Sciences, School of Physics, Peking University, Beijing, China \\ ${ }^{2}$ The Institute for the Environment, the Hong Kong University of Science and Technology, Hong Kong, China \\ ${ }^{3}$ Center for Satellite Remote Sensing and Measurement, Shanghai Meteorological Bureau, Shanghai, China \\ ${ }^{4}$ Weather Modification Office, Shanxi Meteorological Bureau, Taiyuan, China
}

Received: 29 November 2005 - Published in Atmos. Chem. Phys. Discuss.: 18 April 2006

Revised: 7 July 2006 - Accepted: 31 July 2006 - Published: 7 August 2006

\begin{abstract}
The aerosol extinction-to-backscatter ratio is an important parameter for inverting LIDAR signals in the LIDAR equation. It is a complicated function of the aerosol microphysical characteristics. In this paper, a method to retrieve the column-averaged aerosol extinction-to-backscatter ratio by constraining the aerosol optical depths (AOD) from a Micro-pulse LIDAR (MPL) by the AOD measurements from the Moderate Resolution Imaging Spectroradiometer (MODIS) is presented. Both measurements were taken on cloud free days between 1 May 2003 and 30 June 2004 over Hong Kong, a coastal city in south China. Simultaneous measurements of aerosol scattering coefficients with a forward scattering visibility sensor are compared with the LIDAR retrieval of aerosol extinction coefficients. The data are then analyzed to determine seasonal trends of the aetrosol extinction-to-backscatter ratio. In addition, the relationships between the extinction-to-backscatter ratio and wind conditions as well as other aerosol microphysical parameters are presented. The mean aerosol extinction-to-backscatter ratio for the whole period was found to be $29.1 \pm 5.8 \mathrm{sr}$, with a minimum of $18 \mathrm{sr}$ in July 2003 and a maximum of $44 \mathrm{sr}$ in March 2004. The ratio is lower in summer because of the dominance of oceanic aerosols in association with the prevailing southwesterly monsoon. In contrast, relatively larger ratios are noted in spring and winter because of the increased impact of local and regional industrial pollutants associated with the northerly monsoon. The extended LIDAR measurements over Hong Kong provide not only a more accurate retrieval of aerosol extinction coefficient profiles, but also significant substantial information for air pollution and climate studies in the region.
\end{abstract}

Correspondence to: C. C. $\mathrm{Li}$

(ccli@pku.edu.cn)

\section{Introduction}

Atmospheric aerosols play an important role in the earth's radiation budget. They influence the lifetime and microphysical properties of clouds, precipitation rates and tropospheric photochemistry (IPCC, 2001; Twomey, 1977; Lohmann and Feichter, 1997; Phadnis and Carmichael, 2000), and hence are very important in climate change study (Charlson et al., 1992). However, there are still many outstanding problems related to the determination of their physical and chemical properties, as well as their spatial and temporal distributions (Andreae and Crutzen, 1997). In particular, our understanding of the aerosol vertical structure is still very limited because of its high spatial and temporal variability.

To characterize the optical properties of atmospheric aerosols, as well as their spatial and temporal distributions, the LIDAR (Light Detection and Ranging) method has proven to be very useful (Collis and Russell, 1976; Sassen and Cho, 1992; Welton et al., 2002). However, retrieval of the aerosol extinction profile from backscattered LIDAR measurements requires knowledge of the aerosol extinctionto-backscatter ratio (Fernald, 1984). In previous studies, this problem has been solved by using the high spectral resolution LIDAR techniques (Grund and Eloranta, 1991) or elasticRaman LIDAR measurements (Ansmann et al., 1992), which have been automatically running in Oklahoma and in the Arctic as well as in the framework of EARLINET (Razenkov et al., 2004; Mattis et al., 2004) since 2000. Although both techniques allow simultaneous determination of the aerosol extinction and backscattered coefficients, one should bear in mind that both signals are sensitive to the background noise induced by scattering from ambient aerosol. Therefore, they are more appropriate for use in clean conditions like those of the Arctic and Europe. Under the circumstances of heavy aerosol loading, such as the heavy haze events occurring

Published by Copernicus GmbH on behalf of the European Geosciences Union. 
frequently in South China, the above mentioned techniques might have significant errors in the retrieval of the LIDAR signal and may not be easily employed in long-term daytime observations of aerosol optical properties.

The aerosol extinction-to-backscatter ratio, or the LIDAR ratio (LR), is often used to analyze the elastic-LIDAR signal in the two-component LIDAR equation. In general, LR is a complicated spatial and temporal function which depends on the size distribution, shape and composition of the aerosols. Furthermore, the microphysical characteristics of aerosols can be classified according to their geographical origin such as urban, rural, marine or continental, and also to local meteorological conditions. Typically, different but constant LRs are assumed and used for different types of aerosols. Many studies (Sasano et al., 1985; Kovalev, 1995) show that an inaccurate assumption of LR can lead to large errors in the retrieval of aerosol extinction coefficients, particularly under inhomogeneous atmospheric conditions where the aerosolto-molecular extinction ratio is highly varying. Therefore, LR must be estimated carefully with respect to the geographical location and meteorological conditions of the measurement site.

Extended observations of the aerosol extinction-tobackscatter ratio have been carried out during recent years, despite the difficulty noted earlier, leading to to an explosive growth in the number of literatures on the measurement of LR in America, Asia and Europe. Table 1 lists the LR observed worldwide. Unfortunately, there are limited observations of LR in China, especially in the Pearl River Delta region, one of the most rapidly developing and heavily industrialized regions of southern China. Previous studies show that the value of the LR varies from 20 to $100 \mathrm{sr}$ (Collis and Russel, 1976; Zuev, 1982; Browell et al., 1985). Experimental studies have also been carried out concerning the variability of the LR by using data from a nephelometer at wavelength of $680 \mathrm{~nm}$ and a ruby LIDAR at wavelength of $694 \mathrm{~nm}$. Waggoner et al. (1972) retrieved an aerosol scattering-to-backscatter ratio of about $84 \mathrm{sr}$ for the relative humidity smaller than $75 \%$. A decade later, Salemink et al. (1984) showed a linear increase in the LR from 25 to $70 \mathrm{sr}$ for the relative humidity of $40-80 \%$ at wavelength of $532 \mathrm{~nm}$ near the ground. Using climatological values of aerosol size distributions, Ackermann (1998) modeled LR values for different tropospheric aerosol types at typical wavelengths ( $355 \mathrm{~nm}, 532 \mathrm{~nm}$ and $1064 \mathrm{~nm}$ ) using Nd:YAG lasers. More recently, Ferrare et al. (1998) showed that a significant change in the LR is likely at the top of the atmospheric boundary layer (ABL).

In the absence of direct LR measurements, columnaveraged LR may be estimated by constraining the vertical integral of LIDAR-derived aerosol extinction coefficients with independent aerosol optical depth measurements (Welton et al., 2000; Chazette, 2003). Ansmann et al. (2002) showed combined observations with a multi-wavelength Sun photometer and a six wavelength backscatter LIDAR, and discussed all the necessary input parameters. Generally, this method can be applied to LIDAR acquisitions in parallel with sunphotometer measurements.

In this paper, we shall present a method to estimate the May 2003 to June 2004 variations of the aerosol extinctionto-backscatter ratio by constraining the AOD measurements from a MPL with AOD measurements from MODIS. A similar study recently shows good comparison between Meteosat and LIDAR data (Dulac and Chazette, 2003). For the first time, MODIS data are used to estimate the extinction-tobackscatter ratio. In addition, aerosol extinction coefficients near the surface are obtained by retrieving the MPL signals, and compared with measurements from a collocated visibility sensor. Finally, the monthly and seasonal characteristics of the LR, and the relationship of the LR with meteorological conditions and optical parameters are also summarized.

\section{Measurements}

Two Moderate Resolution Imaging Spectroradiometers (MODIS) were launched aboard the polar orbiting spacecrafts Terra (December 1999) and Aqua (May 2002). For the past few years, global data have been taken daily in 36 spectral bands from the visible to the thermal infrared, with 29,5 and 2 of these bands at $1 \mathrm{~km}, 500 \mathrm{~m}$ and $250 \mathrm{~m}$ nadir pixel dimensions, respectively. A detailed description of the MODIS data can be found in Kaufman et al. (1997). Terra's sun-synchronous orbit has a dayside equatorial local crossing time at 11:00 a.m. and the corresponding time for Aqua is 03:00 p.m. Kaufman and Tanre (1998) described two separate algorithms for aerosol retrieval from MODIS over land and ocean surfaces. Aerosol products are stored as MODIS Level 2 (MOD04 L2) files, each corresponding to five-minute acquisition along the satellite orbit. The Level 2 AODs are processed and archived at a spatial resolution of $10 \times 10 \mathrm{~km}$ (at nadir). To assess the quality of these parameters, a substantial part of the Terra-MODIS aerosol products have been validated globally and regionally (Chu et al., 2002; Remer et al., 2005). The validation process is also under continuous development to ensure a high product quality. As discussed in MODIS aerosol product validation studies, the accuracy of the MODIS AOD retrievals over land is estimated to be $\triangle \mathrm{AOD}= \pm 0.05 \pm 0.2 \mathrm{AOD}$ (Chu et al., 2002), indicating the relative error of the retrieved AOD is $20 \%$ in general conditions (e.g. AOD $>0.3$ ) and the absolute error reaches the value of 0.05 when AOD is relatively small $(\mathrm{AOD}<0.2)$. Similar accuracy has also been estimated to be $\triangle \mathrm{AOD}= \pm 0.05 \pm 0.15 \mathrm{AOD}$ by Remer et al. (2005).

Aerosol characteristics are mainly determined by the geographical and climatological features of the observation sites. An MPL system, operated by the Hong Kong University of Science and Technology (HKUST), is located at Yuen Long $\left(22.44^{\circ} \mathrm{N}, 114.02^{\circ} \mathrm{E}\right)$, an urban area in the northwestern part of Hong Kong. Hong Kong is a densely populated city with 
Table 1. Lidar ratios observed in worldwide locations.

\begin{tabular}{|c|c|c|c|}
\hline methodology & Aerosol type and location & period & $\mathrm{LR}, \mathrm{sr}^{\mathrm{a}}$ \\
\hline $\begin{array}{l}\text { Raman lidar } \\
\text { Ferrare et al. (2001) }\end{array}$ & $\begin{array}{l}\text { Southern Great Plains in north central Okla- } \\
\text { homa }\end{array}$ & 1998-1999 & $68 \pm 12(355)$ \\
\hline $\begin{array}{l}\text { Raman lidar } \\
\text { Ansmann et al. (2001) }\end{array}$ & $\begin{array}{l}\text { The polluted continental air over Sagres in } \\
\text { Portugal }\end{array}$ & Summer of 1997 & $30-80(532)$ \\
\hline six-wavelength aerosol & Hulule island in the Indian Ocean & February 1999-March 2000 & $(532)$ \\
\hline $\begin{array}{l}\text { lidar } \\
\text { Muller et al. (2001b) }\end{array}$ & $\begin{array}{l}\text { Air masses from India and Southeast Asia } \\
\text { Mixture of clean-marine and clean- } \\
\text { continental aerosol conditions } \\
\text { Clean-marine conditions }\end{array}$ & & $\begin{array}{l}45-75 \\
35-55 \\
20-30\end{array}$ \\
\hline $\begin{array}{l}\text { six-wavelength aerosol } \\
\text { lidar } \\
\text { Muller et al. (2002) }\end{array}$ & $\begin{array}{l}\text { Sagres, Portugal (ACE 2) } \\
\text { Air masses advected from northeastern and } \\
\text { central parts of the European continent } \\
\text { Maritime background aerosol }\end{array}$ & June-July 1997 & $\begin{array}{l}(532) \\
>40 \\
20-40\end{array}$ \\
\hline $\begin{array}{l}\text { six-wavelength aerosol } \\
\text { lidar } \\
\text { Ansmann et al. (2002) }\end{array}$ & $\begin{array}{l}\text { Sagres, Portugal (ACE 2) } \\
\text { Pollution plumes from the European conti- } \\
\text { nent }\end{array}$ & June-July 1997 & $\begin{array}{l}(532) \\
30-65\end{array}$ \\
\hline $\begin{array}{l}\text { six-wavelength aerosol } \\
\text { lidar } \\
\text { Muller et al. (2003) }\end{array}$ & $\begin{array}{l}\text { Hulhule Island, Maldives (INDOEX) } \\
\text { Air masses originated from the polluted In- } \\
\text { dian subcontinent } \\
\text { From northern India } \\
\text { Southeast Asia plumes } \\
\text { From southern India }\end{array}$ & February/March 1999 & $\begin{array}{l}(532) \\
51-60 \\
60-90 \\
\sim 50 \\
<50\end{array}$ \\
\hline $\begin{array}{l}\text { Raman lidar, Mie lidar } \\
\text { Nephelometer and } \\
\text { PASP onboard C-130 } \\
\text { Murayama et al. (2003) }\end{array}$ & $\begin{array}{l}\text { Tokyo,Japan } \\
\text { Asia dust aerosol }\end{array}$ & 23 April 2001 & $\begin{array}{l}(532) \\
46.5 \pm 10.5 \\
50.4 \pm 9.4\end{array}$ \\
\hline $\begin{array}{l}\text { Dual-wavelength } \\
\text { Raman lidar } \\
\text { Mattis et al. (2002) }\end{array}$ & $\begin{array}{l}\text { Long-range Saharan dust outbreaks in } \\
\text { Leipzig, Germany }\end{array}$ & August and October 2001 & $\begin{array}{l}55-65(532) \\
60-70(355)\end{array}$ \\
\hline $\begin{array}{l}\text { Dual-wavelength } \\
\text { Raman lidar } \\
\text { Mattis et al. (2004) }\end{array}$ & $\begin{array}{l}\text { Leipzig, Germany (EARLINET) } \\
\text { Three-year mean } \\
\text { the upper part of the PBL } \\
\text { Free troposphere }\end{array}$ & May 2000-March 2003 & $\begin{array}{l}58(355) \\
45(1064) \\
53(532) \\
52(355) \\
53(532)\end{array}$ \\
\hline $\begin{array}{l}\text { Dual-wavelength } \\
\text { Raman lidar } \\
\text { Muller et al. (2005) }\end{array}$ & $\begin{array}{l}\text { Leipzig, Germany } \\
\text { Well-aged forest fire plumes }\end{array}$ & May-August 2003 & $\begin{array}{l}21-67(355) \\
26-87(532)\end{array}$ \\
\hline $\begin{array}{l}\text { Raman lidar } \\
\text { Muller et al. (2004) }\end{array}$ & $\begin{array}{l}\text { An intense haze event from the Arctic re- } \\
\text { gions across eastern Europe and Scandinavia } \\
\text { over Leipzig, Germany }\end{array}$ & April 2002 & $\begin{array}{l}(355 \& 532) \\
35-75\end{array}$ \\
\hline $\begin{array}{l}\text { Raman lidar } \\
\text { Sakai et al. (2003) }\end{array}$ & The Asian dust in Tsukuba, Japan & 2001 and 2002 & $\begin{array}{l}(532) \\
>30(\text { RH }<50 \%) \\
<30(\text { RH=100\%) }\end{array}$ \\
\hline $\begin{array}{l}\text { Dual-wavelength } \\
\text { Raman lidar } \\
\text { Balis et al. (2003) }\end{array}$ & $\begin{array}{l}\text { Young biomass burning aerosol in the free } \\
\text { troposphere over Thessaloniki, Greece }\end{array}$ & Summer of 2001 & $\begin{array}{l}60(355) \\
50(532)\end{array}$ \\
\hline $\begin{array}{l}\text { Raman lidar } \\
\text { De Tomasi and Perrone } \\
(2003)\end{array}$ & $\begin{array}{l}\text { Southern Italy (EARLINET) } \\
\text { Advected northern and eastern Europe air } \\
\text { masses } \\
\text { Air masses advected from North Africa }\end{array}$ & July-December 2000 & $\begin{array}{l}(351) \\
50-63 \\
48-74\end{array}$ \\
\hline $\begin{array}{l}\text { Raman lidar } \\
\text { De Tomasi et al. (2003) } \\
\text { Raman elastic- } \\
\text { backscatter lidar } \\
\text { Pappalardo et al. } \\
\text { (2004) }\end{array}$ & $\begin{array}{l}\text { Strong African dust outbreaks at Lecce in the } \\
\text { southeastern corner of Italy } \\
\text { Etna volcano aerosol layer over IMAA-CNR } \\
\text { (Potenza, Italy) }\end{array}$ & $\begin{array}{l}17 \text { May } 2001 \text { between } 18: 55 \\
\text { and 20:07 UT } \\
\text { 1-2 November } 2002\end{array}$ & $\begin{array}{l}(351) \\
50 \\
(355) \\
55\end{array}$ \\
\hline
\end{tabular}

${ }^{a}$ numbers in parentheses represent wavelength in the unit of nanometer (nm). 
Table 2. Monthly number of simultaneous MPL and MODIS measurements over Hong Kong during May 2003-June 2004.

\begin{tabular}{ll}
\hline Month & $\begin{array}{l}\text { Number of } \\
\text { measurements }\end{array}$ \\
\hline May 2003 & 2 \\
June 2003 & 4 \\
July 2003 & 14 \\
August 2003 & 4 \\
September 2003 & 14 \\
October 2003 & 11 \\
November 2003 & 20 \\
December 2003 & 15 \\
February 2004 & 3 \\
March 2004 & 2 \\
April 2004 & 2 \\
May 2004 & 3 \\
June 2004 & 1 \\
\hline
\end{tabular}

an area of just over $1100 \mathrm{~km}^{2}$ and a population of 6.8 million. It is adjacent to the Pearl River Delta (PRD) region, which is one of the most rapidly developing and heavily industrialized regions in southern China along the north coast of the South China Sea (Cao et al., 2003). In this regard, the MPL station in Yuen Long is useful for monitoring both oceanic and continental aerosols.

The MPL has been operated automatically and almost continuously around the clock since May 2003. The site, at the rooftop of a building, is $28 \mathrm{~m}$ above ground level (AGL). The bin time of the MPL receiver is set to $200 \mathrm{~ns}$, corresponding to a vertical spacial resolution of $30 \mathrm{~m}$. The MPL pulse repetition rate is $2500 \mathrm{~Hz}$ and the wavelength is $523 \mathrm{~nm}$ (Nd:YLF). Backscattering signals of the MPL are recorded every 15 s. Data from 1 May 2003 to 30 June 2004, except for a maintenance period from 18 December 2003 to 13 February 2004, are used in this study. Data on cloud-free days, when the MPL and satellite data are both simultaneously available, are selected for analysis. The monthly numbers of selected days are listed in Table 2. There are totally 95 measurements in this period. MPL signals are averaged within a time window of $\pm 30 \mathrm{~min}$ around the satellite overpassing time for use in the retrieval.

The aerosol scattering coefficients from a Belfort Model 6000 visibility sensor are used in this study. This visibility sensor is detected using widely accepted principles of forward scattering. A high output infrared LED transmitter projects light at wavelength of $910 \mathrm{~nm}$ into a sample volume, and the light scattered in a forward direction of about $42 \mathrm{de}-$ grees is collected by the receiver. The light source is modulated to provide an excellent rejection of background noise and natural variations in background light intensity. It is calibrated once every six months in our experiment period with a calibration kit provided by its manufactory Belfort Instru- ment Company. Total atmospheric scattering coefficients are directly included in the digital output. Aerosol scattering coefficients can be obtained by extracting molecule scattering parts evaluated by the Rayleigh-scattering theory.

\section{Methodology}

The columnar LR value is constrained by comparing the LIDAR-derived AOD at wavelength of $523 \mathrm{~nm}$ with the independent MODIS-derived AOD data at wavelength of $550 \mathrm{~nm}$. The procedure consists of three main steps:

3.1 Retrieval of aerosol extinction coefficient from the LIDAR measurements

In general, the inversion of the LIDAR profile is based on the solution of the single scattering LIDAR equation:

$P(r)=O_{c}(r) C E \frac{\beta(r)}{r^{2}} \exp \left[-2 \int_{0}^{r} \sigma(z) d z\right]$

where $r$ is the range, $\beta(r)$ represents the total backscattering coefficient $\beta(r)=\beta_{m}(r)+\beta_{a}(r), \sigma(r)$ is the total extinction coefficient $\sigma(r)=\sigma_{m}(r)+\sigma_{a}(r), C$ is the LIDAR constant, which incorporates the transmission and the detection efficiency, and $E$ is the laser pulse energy. $\beta_{m}(r)$ and $\sigma_{m}(r)$ are molecular contributions to the backscattering and the extinction coefficients, respectively. They can be evaluated by the Rayleigh-scattering theory from the Standard Atmosphere 1976 (NASA, 1976). $O_{c}(r)$ is the overlap correction as a function of the range caused by field-of-view conflicts in the transceiver system. Systematic errors of $\mathrm{P}(\mathrm{r})$ were mainly observed in the lowest altitudes where an incomplete overlap between the emitted laser beam and the telescope field-of-view can led to an underestimation of aerosol backscatter and extinction coefficients. Since the majority of aerosols are contained in the first several kilometers of the atmosphere, the overlap problem must be solved. Overlap is typically solved experimentally, using techniques outlined by Campbell et al. (2002). The starting point is an averaged data sample where the system is pointed horizontally with no obscuration. By choosing a time when the atmosphere is well mixed, such as late afternoon, or, even better, when the aerosol loading is low, backscattering through the layer is roughly assumed to be constant with range (i.e., the target layer is assumed to be homogeneous). The similar overlap calibration was carried out every three months in the study period. Figure 1 presents an example of the overlap correction derived in Hong Kong at local time (UTC+8) 14:30 14:40 on 11 March 2003, and data within the range up to $4 \mathrm{~km}$ are needed to be corrected by the overlap correction function. The uncertainty of the overlap correction is discussed in detail by Welton et al. (2002). In this study the uncertainty of the overlap correction is estimated to be less than $10 \%$. The received signals are normalized to the 
laser source, noise-subtracted, and square-range corrected. The overall error in the aerosol backscattered signals arose from many sources, including uncertainty of $C$, errors in the background and noise-subtraction, and nonlinearities in the detecting electronics. In this study, we have not taken into account effects of multiple scattering. Using numerical methods, Ackermann et al. (1999) studied the influence of multiple scattering on the retrieval of extinction coefficients of the tropospheric aerosols, and their simulation shows that the contribution from multiple scattering in the LIDAR signal is typically less than $10 \%$ and never exceeds $20 \%$ (based on the assumption of a constant extinction coefficient below the ABL (chosen at 15.65, 3.91, 1.96, 0.783, and $0.078 \mathrm{~km}^{-1}$ ), and an exponential decay value above the ABL). For all types of aerosols in the urban environment, the contribution of multiple scattering on the retrieved aerosol extinction profile in the ABL is found to be less than $3 \%$. Neglecting multiple scattering, the LIDAR equation has three unknowns $C$, $\beta_{a}(r)$, and $\sigma_{a}(r)$.

The stable analytical inversion procedure proposed by Klett (1985) is more effective for optically thick atmospheric conditions, and does not have any particular advantage in the present situation with small optical depths. To determine the aerosol backscatter $\beta_{a}(r)$ and extinction coefficient $\sigma_{a}(r)$, Fernald's (1984) forward inversion scheme is used for the LIDAR signal inversion:

$$
\begin{aligned}
\sigma_{a}(r) & =\frac{X(r) \exp \left[2(1-s) \int_{0}^{r} \sigma_{m}(z) d z\right]}{\frac{C}{s_{a}}-2 \int_{0}^{r} X(z) \exp \left[2(1-s) \int_{0}^{z} \sigma_{m}\left(z^{\prime}\right) d z^{\prime}\right] d z} \\
& -s \sigma_{m}(r)
\end{aligned}
$$

where $r$ is the range, $X(r)=P(r) \cdot r^{2}, \quad s=s_{a} / s_{m}$ where $s_{m}=(8 \pi / 3)$ is the molecular extinction to backscatter ratio, and $s_{a}$ is LR.

To determine $\sigma_{a}(r)$ in Eq. (2), the value of LR and the LIDAR constant $C$ must be known. The retrieval of LR will be discussed in detail in Sect. 3.3. $C$ is a main source of systematic error for $\sigma_{a}(r)$, and its calibration is performed experimentally by using independently measured AODs from a Microtops Sun photometer for four separate days (12 May, 30 August, 17 October 2003, and 17 February 2004) (Welton et al., 2000). The accuracy of the calibration is estimated to be $\pm 5 \%$. The variability in the calibration coefficient derived at intervals during the measurement period is steady and monotone, suggesting that the calibration coefficient from interpolation between the measured ones can be used to retrieve $\sigma_{a}(r)$ without significant error. Although the overall error in the aerosol extinction coefficient cannot be precisely computed, it is estimated to be $20-30 \%$ at wavelength of $523 \mathrm{~nm}$.

\subsection{Validation of MODIS AOD product}

MODIS AOD within $0.2^{\circ} \times 0.2^{\circ}$ (i.e. about $20 \times 20 \mathrm{~km}$ pixels) around the MPL site is selected to constrain the LIDAR AOD, corresponding to the detail geographical area within a latitude range of $22.34^{\circ} \mathrm{N}$ to $22.54^{\circ} \mathrm{N}$ and a lon-

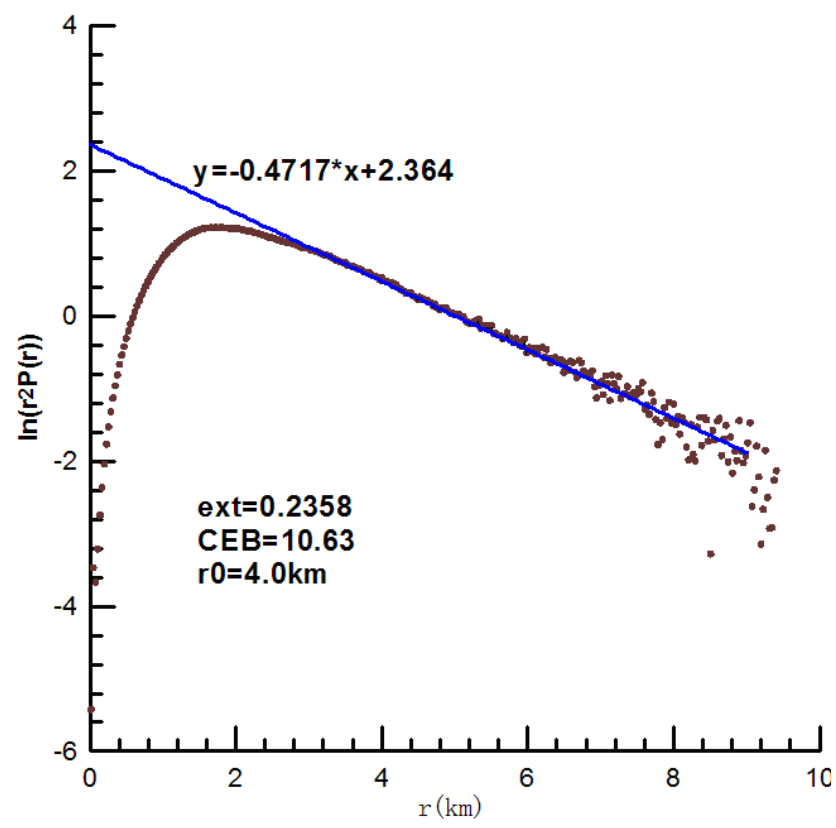

Fig. 1. Overlap correction of the MPL signal (at local time (UTC+8) 14:30 14:40 on 11 March 2003, Hong Kong). The scatter plot is range-corrected signal from MPL and the line $y=-0.4717 x+2.364$ is the least squares linear fit to the data between 4 and $6 \mathrm{~km}$. The extinction coefficient is $0.2358 \mathrm{~km}^{-1}$, and the full overlap is reached at approximately $4.0 \mathrm{~km}$.

gitude range of $113.92^{\circ} \mathrm{E}$ to $114.12^{\circ} \mathrm{E}$. Recently, Remer et al. (2005) compared 5906 MODIS AOD retrievals with AERONET measurements and confirmed that one standard deviation of the MODIS AOD retrievals falls within the predicted uncertainty of $\triangle \mathrm{AOD}= \pm 0.05 \pm 0.15 \mathrm{AOD}$ over land at a wavelength of $550 \mathrm{~nm}$. Li (2002) and Li et al. (2003) compared AODs derived from the sunphotometer with a MODIS level 2 AOD product for almost 2 years, and concluded that the level 2 MODIS AOD product is of a high precision over South China where the surface reflectivity is relatively low for visible wavelengths due to dense perennial vegetation coverage in the region.

\subsection{Retrieval of LR}

A "Look-up Table" approach based on inter-comparison of AOD values derived from MPL and MODIS data is used in the retrieval of LR. Given the uncertainties of the AOD retrievals, the difference in wavelengths is negligible between MODIS and MPL measurements. Paolo Di Girolamo (1999) noted that the overall variability of LR in the $355-723 \mathrm{~nm}$ spectral range does not exceed $15 \%$ for aerosol size range of $0.1 \mu \mathrm{m}$ to $1.0 \mu \mathrm{m}$. When LR increases monotonically from 5 to 100 in unit steps, different vertical profiles of the extinction coefficient at wavelength of $523 \mathrm{~nm}$ can be derived with Eq. (2). The AOD value can then be obtained from the integral of the extinction coefficient from the surface 


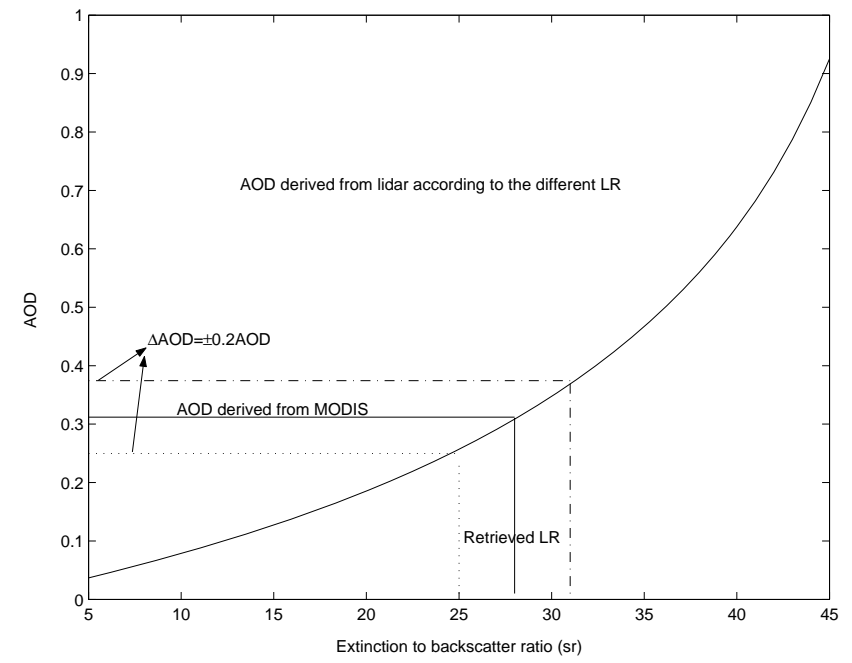

Fig. 2. An example of LR retrieval by constraining the LIDAR AOD with MODIS AOD. The curve is the LIDAR AOD obtained with different LRs. The horizontal solid line is the MODIS AOD measurement, and the vertical line dropped at its intersection with the curve defines the best LR. The maximum error in AOD is shown by the horizontal dotted and dashed lines, and the maximum error in LR is shown by the vertical dotted and dashed line).

(ground level) up to $4 \mathrm{~km}$, assuming the absence of stratospheric aerosols. Elastic LIDAR measurements show that aerosols in those very high layers contribute very little to the total AOD. Additionally, for the lowest layer $(0 \sim 130 \mathrm{~m})$, the aerosol extinction coefficient closest to the ground is chosen to represent the extinction at the missing heights when calculating AODs. Figure 2 shows an example of a typical retrieval process for the LR. The LR value that leads to the LIDAR AOD closest to the MODIS AOD is defined to be the best-estimated extinction-to-backscatter ratio during the observation period. The process is constrained specifically so that the AOD derived from the MPL data is equal to the one from MODIS data at wavelength of $550 \mathrm{~nm}$ during the days selected. In the figure we can see that the best agreement between the AODs from both measurements is obtained at an LR value of $28 \mathrm{sr}$. The relative uncertainty of the MODIS measurements yields an uncertainty of \pm 3 sr for LR. Finally, we also note that the vertical profiles of the extinction coefficient are based on the averaged measurements from MPL cloud-free data taken over every $60 \mathrm{~min}$.

\section{Results}

4.1 Inter-comparison of MPL retrieved extinction coefficient with scattering coefficient

It is difficult to validate the retrieval results due to the lack of in-situ measurements, but it is feasible to evaluate the LR by comparing the near-surface (AGL $\sim 130 \mathrm{~m}$ ) aerosol extinction
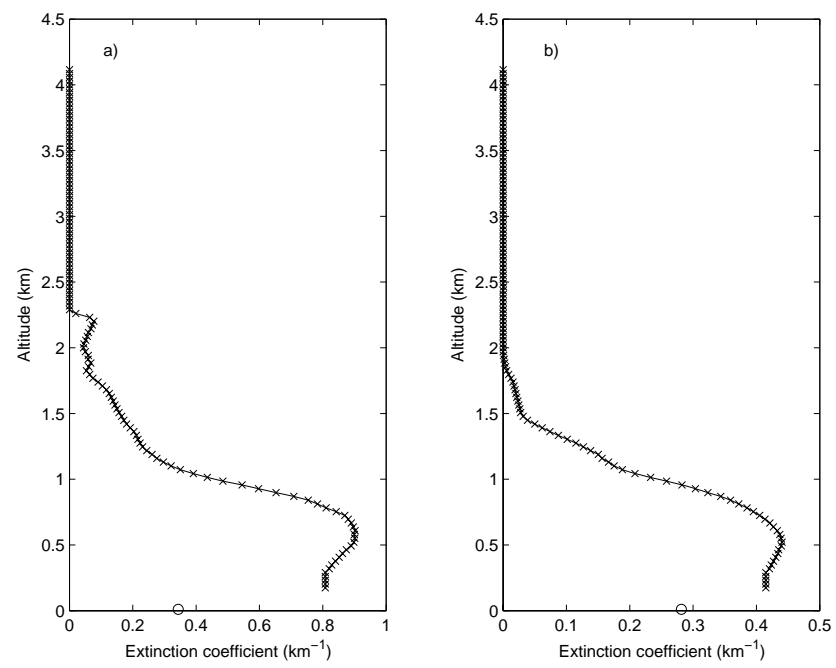

Fig. 3. The hourly averaged aerosol extinction coefficient profiles retrieved from the MPL data (solid line with asterisk) and the visibility sensor data (circles on the $\mathrm{x}$-axis): (a) at 11:00 a.m. on 1 November 2003 (LR=36 sr and MODIS AOD=0.87) and (b) at 01:00 p.m. on 27 November 2003 ( $L R=23 \mathrm{sr}$ and MODIS $\mathrm{AOD}=0.41)$.

coefficients derived from the LIDAR with the surface scattering coefficients from the Belfort forward visibility sensor.

Figure 3 shows the hourly averaged vertical aerosol extinction coefficient profiles retrieved from the MPL data with the above determined LR (a) at local time 11:00 12:00 a.m. on 1 November 2003 and (b) at local time 01:00 02:00 p.m. on 27 November of 2003. The corresponding AODs were found to be $0.87(\mathrm{LR}=36 \mathrm{sr})$ and $0.41(\mathrm{LR}=23 \mathrm{sr})$, respectively. The simultaneous aerosol scattering coefficients at $910 \mathrm{~nm}$ obtained by the visibility sensor are plotted on the $\mathrm{x}$-axis. In Fig. 3a the LIDAR-derived surface extinction coefficient is about $0.808 \mathrm{~km}^{-1}$, which is the value closest to the ground level (AGL $\sim 130 \mathrm{~m}$ ) in the vertical aerosol extinction coefficient profile. In contrast, the visibility sensor measured an aerosol scattering coefficient of $0.344 \mathrm{~km}^{-1}$. For discrete aerosol layers found above $2 \mathrm{~km}$, this can be attributed to the residual layer formation from the previous day or migration from remote areas. The value of LR is comparable with the values found during the INDOEX experiment over urban areas in the Asian tropical regions (Muller et al., 2001a). The Ångström exponent value of 0.84 from MODIS level 2 products indicates the presence of bigger particles in the atmosphere, such as mineral and dust aerosols, possibly originating from industrial and urban activities in the city. This can further be verified by analyzing the corresponding satellite data as well as the air mass back-trajectory.

Figure 4 shows the MODIS AOD data over the PRD region at local time 11:20 a.m. on 1 November 2003. High AOD values were found in the north-western part of Hong Kong, indicating the presence of advected aerosols 


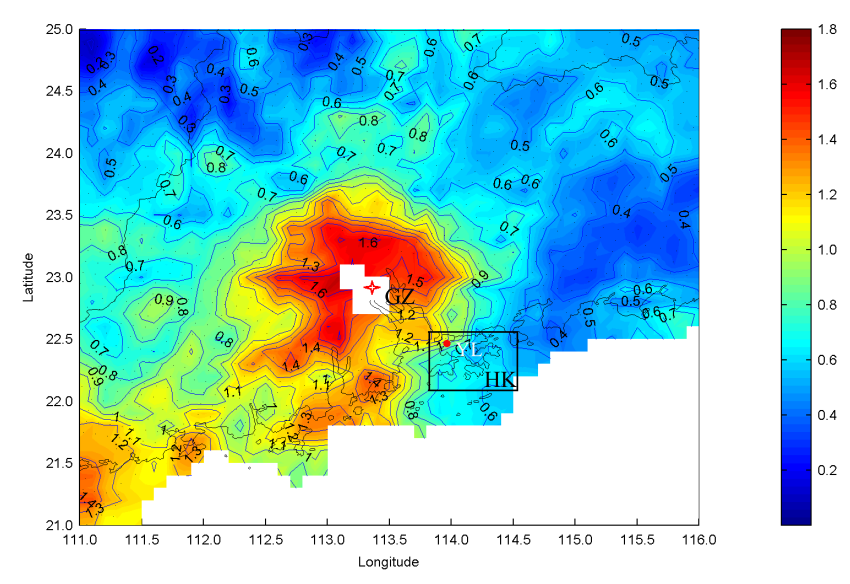

Fig. 4. Level 2 MODIS aerosol optical depth (MOD04, version 4) at local time 11:20 a.m. on 1 November 2003. The highly turbid air mass originated from the center of the Pearl River Delta was transported to its surroundings. The MPL site (Yuen Long, YL) is marked on the top left corner of the inner rectangular box showing Hong Kong (HK), Guangzhou (GZ), a large city in South China is also marked on the center of high AOD contours.

$(0.8<\mathrm{AOD}<1.2)$ from local urban activities or industrial sources in the PRD region. The blank area in Fig. 4 near Guangzhou (marked "GZ" in the center of the figure) has no AOD measurements from MODIS for cloud mask algorithm suggests the existence of clouds. However, this may be an error in the cloud mask algorithm under the conditions of considerable AOD loading existing over the PRD region.

In Fig. 3b MPL extinction profiles indicate that aerosols are mainly confined below $1.5 \mathrm{~km}$ for a moderate pollution condition. The LIDAR-derived surface extinction coefficient is about $0.415 \mathrm{~km}^{-1}$, while the visibility sensor measured a scattering coefficient of $0.282 \mathrm{~km}^{-1}$ at wavelength of $910 \mathrm{~nm}$. The aerosol extinction-to-backscatter ratio of $23 \mathrm{sr}$ on this day can be considered as a typical value for maritime aerosols. The MODIS measured Ångström exponent is 0.46, indicating the presence of slightly larger particles in the atmosphere, such as sea salt and mineral aerosols. In fact, over urban or industrial areas, optical properties are dominated by fine particles (Dubovik et al., 2002). Under maritime conditions, the relative contribution of coarse particles are variable (Smirnov et al., 2002) and generally higher than those over urban or industrial areas but lower than desert dust (Dubovik et al., 2002).

Figure 5 presents the scatter plots of the surface aerosol extinction coefficient observed by the MPL and the scattering coefficient by the visibility sensor. The error-bar on each circle denotes the standard deviation of the hourly-averaged scattering coefficient sensed from the visibility sensor at $910 \mathrm{~nm}$. The slope of the best fit curve of the scatter plots is about 0.5 , showing that the scattering coefficient derived from the visibility sensor is systematically less than the one from MPL. The main reason for the difference is they are

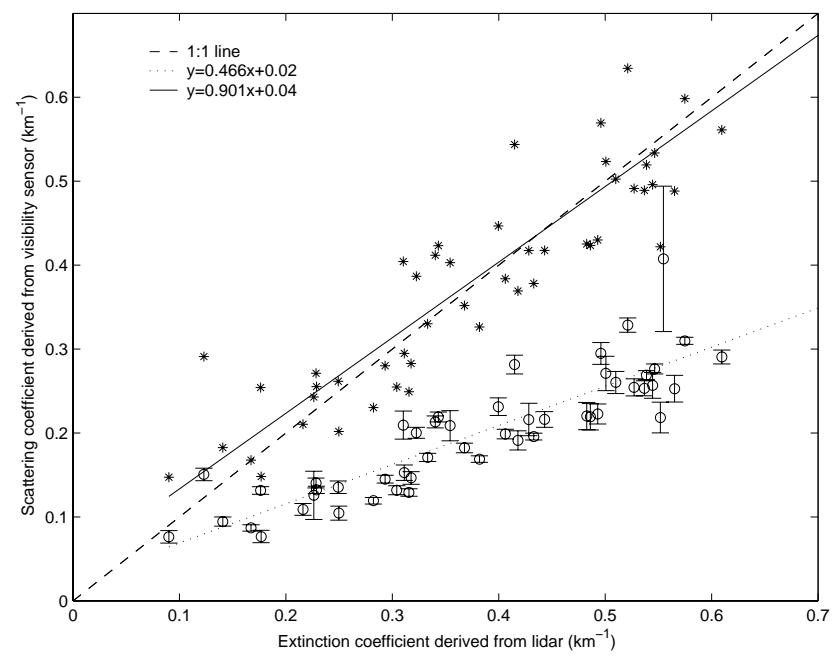

Fig. 5. Inter-comparison of the near-surface aerosol extinction coefficient derived from MPL and the visibility sensor. The error bars on the circles represent the standard deviation of hourly-averaged forward scattering coefficient. The asterisks are the comparison between the extinction coefficient from LIDAR and the ones from the visibility sensor but on $532 \mathrm{~nm}$ LIDAR wavelength which are calculated by a single scattering albedo of 0.9 and aerosol Ångström exponent of 1.0 .

measured on different wavelengths. The LIDAR worked on visible green light (wavelength $523 \mathrm{~nm}$ ); while the forward scattering visibility sensor used an infrared LED at $910 \mathrm{~nm}$ as its light source. The extinction coefficients at infrared should be much less than those at green light obeying the Ångström change with wavelength. Another reason for this difference is the absorption of aerosols. The scattering coefficients measured by the visibility sensor do not include the absorption coefficients. In highly turbid areas such as the PRD, the influence of absorbing aerosol on the extinction coefficient could not be neglected (Ansmann et al., 2005). Considering the above two causes, the aerosol scattering coefficients from the visibility sensor are converted into extinction coefficients at the same wavelength as that of LIDAR according to a single scattering albedo of 0.90 and aerosol Ångström exponent of 1.0 , and the scatter plots of disposed results are represented as asterisks. In this situation, their correlation coefficient remains the same $(\sim 0.91)$ as corrected before. After the correction the slope of the best fit curve is increased to 0.9 and the root mean square error (RMS) is also evidently decreased to $\sim 0.07 \mathrm{~km}^{-1}$ compared with the previous one $\sim 0.21 \mathrm{~km}^{-1}$, which suggest the correction is reasonable. However, the two measurements still have some differences after the correction, especially in highly turbid conditions with a maximum difference of up to $0.6 \mathrm{~km}^{-1}$. The discrepancy may be mostly due to the fact that the comparison is performed at different altitudes, i.e., the MPL data were obtained at $130 \mathrm{~m}$ while the visibility sensor at about $2 \mathrm{~m}$ above ground. Although the measurements were taken around noon (10:00-14:00 local 

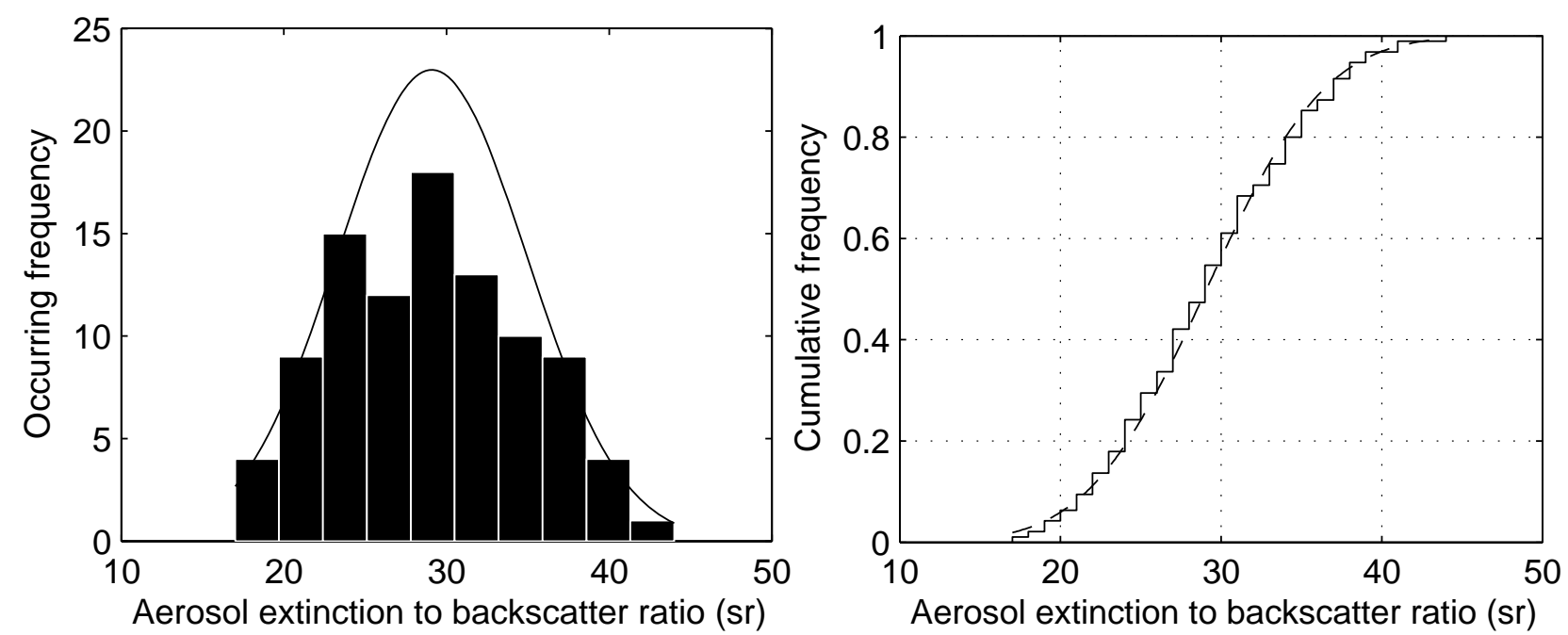

Fig. 6. (a) Frequency distribution and (b) cumulative frequency distribution of the aerosol extinction-to-backscatter ratio over Hong Kong. The solid line in (a) and dashed line in (b) are Gaussian distribution fit curves according to the statistical parameters listed in Table 3.

time) when the boundary layer is generally considered to be well-mixed, the extinction coefficient actually increases with height within the mixing layer, as observed from the available extinction coefficient profile above the missing height; therefore, the extinction coefficient from the visibility sensor may be less than those calculated from the MPL data. Despite all the above sources of error, it can be shown that the extinction coefficients estimated from MPL have a good relationship with in situ measurement of the visibility sensor as their correlation coefficient reaches a value of above 0.90 and the RMS drops to a relatively small value of $0.07 \mathrm{~km}^{-1}$.

The analysis indicates that LR derived by the combination of MPL and MODIS can reasonably represent the actual characteristics of atmospheric aerosols over Hong Kong.

\subsection{Overview of LR characteristics}

For the whole measurement period, the extinction-tobackscatter ratio has an averaged value of $29.1 \pm 5.8 \mathrm{sr}$ with a maximum of $44 \mathrm{sr}$ (5 March 2004) and minimum of $18 \mathrm{sr}$ (15 July 2003) over Hong Kong as estimated from the MODIS AOD and the LIDAR AOD below $4 \mathrm{~km}$. In general, LR can be used to identify the dominant aerosol type (Ackermann, 1998). It is suggested that larger particles accompanied by less-absorbing particles result in smaller LRs and highly absorbing particles should have larger LRs (Ansmann et al., 2001). For maritime aerosols, Ackermann (1998) found the average LR range from $17 \mathrm{sr}$ to $24 \mathrm{sr}$. Recently, De Tomasi and Perrone (2003) reported LR measurements over southeastern Italy with average values ranging from $23 \mathrm{sr}$ to $44 \mathrm{sr}$ for air masses advected from the West Atlantic and Mediterranean Sea. On the southwestern coast of India (Goa), Chazette (2003) reported an average value of $35.7 \pm 10 \mathrm{sr}$ in
February 1999. Muller et al. (2001b), using six-wavelength aerosol LIDAR, retrieved more than one year of LRs ranging from 35 to $55 \mathrm{sr}$ for a mixture of clean-marine and cleancontinental aerosol conditions and from 20 to 30 sr for cleanmarine conditions at wavelength of $532 \mathrm{~nm}$ over Hulule Island in the Indian Ocean. Hence, the mean LR calculated in this study suggests more characteristics similar to those of maritime aerosols.

Figure 6a shows that the modal value of LR (18 out of 95) is observed in the range $27.8 \mathrm{sr}$ to $30.5 \mathrm{sr}$ if all the available LRs are binned into ten equally spaced segments. The solid line denotes the Gaussian distribution fit curve according to the parameters listed in Tables 3. The Gaussian distribution is used to represent the cumulative frequency distribution of the LR. Two tests, namely the Jarque-Bera test and the Lilliefors test, are employed to check the quality of the fitted distribution function. The Jarque-Bera test evaluates the hypothesis that a sample has a normal distribution with an unspecified mean and variance, against the alternative that the sample does not have a normal distribution. The Lilliefors test is similar to the Kolmogorov-Smirnov test except for adjusting the parameters of the normal distribution which is estimated from sample rather than specified in advance. For both tests, threshold values reaching a significance level of 95\% are given in Table 3. We find that both tests accepted the hypothesis that the binned LR distribution approximates a Gaussian distribution at the 95\% confidence level. Figure $6 \mathrm{~b}$ shows the cumulative frequency distribution of the LR (solid line) and Gaussian distribution fit curve (dashed line). 
Table 3. Statistical parameters of extinction-to-backscatter ratio observed in Hong Kong.

\begin{tabular}{|c|c|c|c|c|c|c|c|c|c|}
\hline \multirow{2}{*}{$\begin{array}{l}\text { No. of } \\
\text { sample }\end{array}$} & \multirow[t]{2}{*}{ skewness } & \multirow[t]{2}{*}{ kurtosis } & \multicolumn{3}{|c|}{$\mu$} & \multicolumn{3}{|c|}{$\sigma$} & \multirow{2}{*}{$\begin{array}{c}\text { significance } \\
\text { level }\end{array}$} \\
\hline & & & lower & & upper & lower & & upper & \\
\hline 95 & 0.183 & 2.457 & 27.908 & 29.095 & 30.282 & 5.100 & 5.827 & 6.798 & $95 \%$ \\
\hline
\end{tabular}

\subsection{Seasonal characteristics of LR}

Figure 7 shows the seasonal variation of LR in Hong Kong. In this analysis we take March, June, September and December, respectively, as the first month of spring, summer, autumn and winter. The error bar is the standard deviation of LR in each season. The highest peak of LR is $34.4 \pm 6.9 \mathrm{sr}$ in the spring and the lowest value is $26.4 \pm 6.4 \mathrm{sr}$ in the summer. The lower troposphere over Hong Kong is affected by continental pollutants. By analyzing aircraft data, Kok et al. (1997) found that complex flow patterns are important in controlling both the local and regional transport of pollutants over Hong Kong. Under the influence of Asian pollutants, high values of LR, up to $100 \mathrm{sr}$, and an average of $59 \pm 24 \mathrm{sr}$ have been measured during the FebruaryMarch 1999 INDOEX intensive field experiment (Franke et al., 2001). The monthly mean extinction-to-backscatter ratio of the haze layer over the PRD region in October 2004 is $46.7 \mathrm{sr}$ (Ansmann et al., 2005). Therefore, the higher LR values in spring are quite realistic and due to the influence of the continental outflow over Southern China. In contrast, the lower LR values in the summer are characteristic of maritime aerosols. This interpretation is consistent with the back-trajectory and residence time analysis by Louie (2005), which shows prevailing northeasterly winds from the continent in autumn and winter and a southerly flows from the South China Sea in summer. The Asiatic monsoon is the dominant driver of winds over the PRD region, and significantly influences the local and regional pollutants transport (Chang and Krishnamurti, 1987). In winter, strong radiative cooling over the continent creates a high-pressure anticyclone that drives the cold and dry air from the continent to the ocean, resulting in a weak to moderate northeasterly or strong northerly winds (Murakami, 1979). In spring, moderate northeasterly winds are predominant. In summer, a low-pressure trough draws moist warm air from the ocean towards the continent, resulting in frequent occurrence of precipitation. Finally, in autumn, oceanic southerly weakens while easterly and northeasterly flows become stronger. Over Hong Kong, the persistent northeast monsoon in spring and winter carries pollutants from various potential sources over the southeastern regions of China, while the southerly monsoon brings cleaner maritime air during the summer. In general the different prevailing wind directions in summer

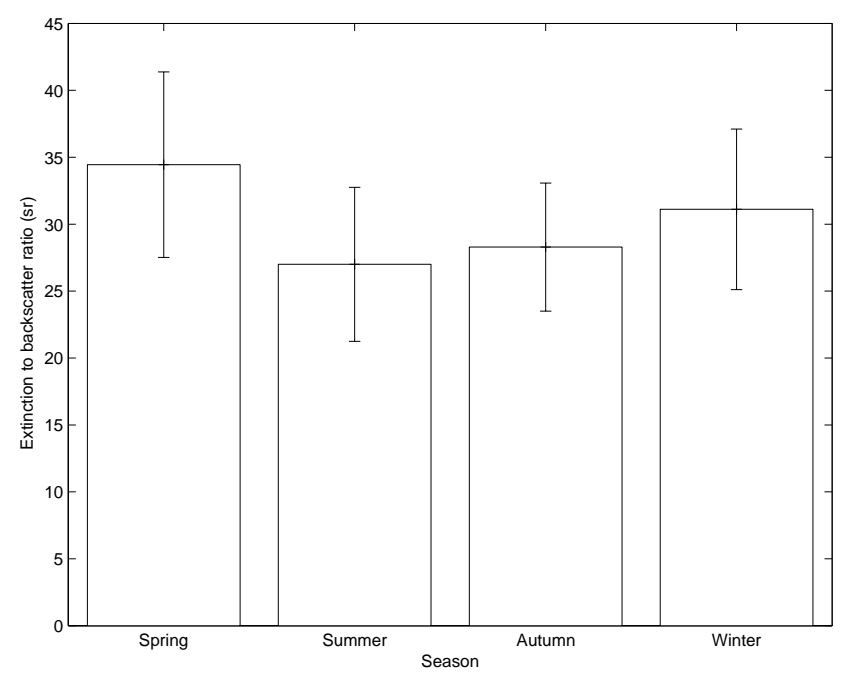

Fig. 7. Seasonal mean aerosol extinction-to-backscatter ratio at $523 \mathrm{~nm}$ derived from MPL together with MODIS AOD measurements in Hong Kong between May 2003 and June 2004. The error bars represent the standard deviation.

and winter are the main cause of the seasonal variations of the LR over Hong Kong.

Table 4 presents the statistical parameters of the seasonal aerosol extinction-to-backscatter ratio, Ångström exponent and surface extinction coefficient observed in Hong Kong. The correlation coefficient is -0.51 in summer indicating a significant anti-correlation between the Ångström exponent and the LR. While the mean LR is $27 \pm 5.8 \mathrm{sr}$ and the mean Ångström exponent is $1.49 \pm 0.68$. The large value of Ångström exponent indicates the existence of smaller particles, possibly pollutant-related. However, the corresponding small value of LR may be attributed to the mixing of some sea-salt aerosols (Ackermann, 1998; Muller et al., 2001a; Franke et al., 2001; Cattrall et al., 2005).

\subsection{Relationship of LR with meteorological conditions and optical parameters}

To understand the variation of LR at a location, it is important to examine the relationship between LR and the various potential pollutant sources. Figure 8 presents the LR distribution in relation to wind direction and wind speed 
Table 4. Statistical values of aerosol extinction-to-backscatter ratio, Ångström exponent and surface extinction coefficient for different seasons.

\begin{tabular}{|c|c|c|c|c|}
\hline & Spring & summer & autumn & winter \\
\hline & \multicolumn{4}{|c|}{ Aerosol extinction-to-backscatter ratio, $s r$} \\
\hline Mean & 34.4 & 27 & 28.3 & 31.1 \\
\hline Std. & 6.9 & 5.8 & 4.8 & 6.0 \\
\hline Maximum & 44 & 37 & 39 & 39 \\
\hline Minimum & 25 & 18 & 19 & 19 \\
\hline \multirow[t]{2}{*}{ Median } & 35 & 26 & 28 & 32.5 \\
\hline & \multicolumn{4}{|c|}{ Angström exponent } \\
\hline Mean & 0.90 & 1.49 & 1.05 & 0.76 \\
\hline Std. & 0.38 & 0.68 & 0.36 & 0.25 \\
\hline Maximum & 1.63 & 2.99 & 2.19 & 1.31 \\
\hline Minimum & 0.49 & 0.41 & 0.41 & 0.31 \\
\hline \multirow[t]{2}{*}{ Median } & 0.87 & 1.48 & 1.03 & 0.72 \\
\hline & \multicolumn{4}{|c|}{ Surface extinction coefficient, $\mathrm{km}^{-1}(\mathrm{MPL})$} \\
\hline Mean & 0.32 & 0.14 & 0.35 & 0.42 \\
\hline Std. & 0.13 & 0.09 & 0.15 & 0.18 \\
\hline Maximum & 0.52 & 0.42 & 0.81 & 0.90 \\
\hline Minimum & 0.09 & 0.05 & 0.09 & 0.12 \\
\hline \multirow[t]{2}{*}{ Median } & 0.32 & 0.11 & 0.33 & 0.43 \\
\hline & \multicolumn{4}{|c|}{ Surface extinction coefficient, $\mathrm{km}^{-1}$ (Visibility sensor } \\
\hline Mean & 0.21 & 0.09 & 0.20 & 0.22 \\
\hline Std. & 0.08 & - & 0.08 & 0.09 \\
\hline Maximum & 0.33 & 0.09 & 0.41 & 0.50 \\
\hline Minimum & 0.08 & 0.09 & 0.08 & 0.13 \\
\hline Median & 0.21 & 0.09 & 0.20 & 0.21 \\
\hline
\end{tabular}

observed by an Automatic Weather Station (AWS) collocated with the MPL. It is seen that the LR values over Hong Kong are lower (18-28 sr) under prevailing southwesterly conditions when oceanic aerosols are being carried over Hong Kong. These low values are also partly due to aerosols composed of sea-salt with negligible absorption. The lowest value of LR found under the northeasterly wind speed (less than $3 \mathrm{~m} / \mathrm{s}$ ) conditions implies that typical oceanic aerosols from the northwest Pacific Ocean have advected to the MPL site. Larger values of LR (up to $40 \mathrm{sr}$ ) are associated with strong southeasterly winds. Moreover, LR may go up to about $40 \mathrm{sr}$ under weak wind conditions regardless of the wind direction; this may be related to the dominance of local urban/industrial emissions with strong absorption near the MPL site. The largest LR values are associated with moderate to strong northwesterly winds (greater than $3 \mathrm{~m} / \mathrm{s}$ ), suggesting that regional transport from the denselypopulated southeastern China may have contributed significant amounts of absorptive aerosols. However, the impact is less significant under moderate-to-weak winds conditions.

Figure 9 shows the relationship of the retrieved LR, the corresponding Ångström exponent and AOD. Here, the mean and standard deviations are computed at nine equally spaced bins of LR. The dashed line represents the best polynomial fit $y=a x^{2}+b x+c$ where $y$ is the AOD (or Ångström exponent), and $x$ is the LR. A least-square procedure was employed to

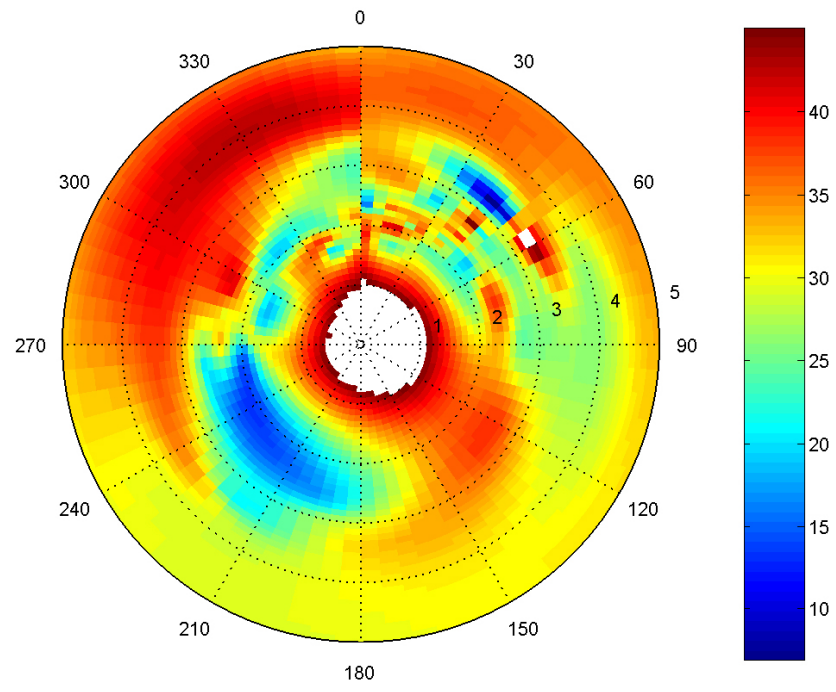

Fig. 8. The variation of aerosol extinction-to-backscatter ratios (unit of color scale is sr) as a function of wind speed and direction.

determine the polynomial fit parameters; these parameters, as well as the correlation coefficients of the fit, are listed in Table 5. Figure 9a shows that a slight increase in AOD is associated with an increasing LR; this may be related to an increase in absorption by aerosols or a relative increase in extinction induced by hygroscopic particles. Figure $9 \mathrm{~b}$ shows that the LR increases as the Ångström exponent decreases, which is different from the study by Ansmann et al. (2001), but similar to the result of Anderson et al. (2003) found for pollution outbreaks advected from China over the Pacific. We note that the Angström exponent is directly related to the slope of a Junge-type size distribution. Because LR is dependent upon the aerosol phase function and the single scatter albedo in the form $S_{a}=\frac{4 \pi}{\omega_{0} P(\pi)}$, it is sensitive not only to changes in particle size, but also to the shape and refractive index. Except for absorptive particles, the large dust like aerosols characterized by a relatively small backscattering component may be responsible for the larger LR. A low Ångström exponent may result from continuous city construction, low plant coverage, ubiquitous local floating dust and large amounts of soot generated from industrial coal combustion and culinary natural gas (Li et al., 2003). Large Ångström exponents and the corresponding small LRs might be related to the mixing of sea-salt and urban aerosols. According to the mean radius of basic aerosol constitution of Standard Radiation Atmosphere (SRA), the effective radius of water-soluble aerosol is smaller than that of soot and dust-like aerosol. We note that water-soluble aerosol is predominant over the PRD, but the particle effective radius will increase due to the manifoldness of soot and/or dust-like aerosol particles as the air parcel becomes more polluted. This implies that (a) the relatively lower optical depth (i.e. in a clean atmosphere) is associated with a small extinction-to-backscatter ratio and (b) 

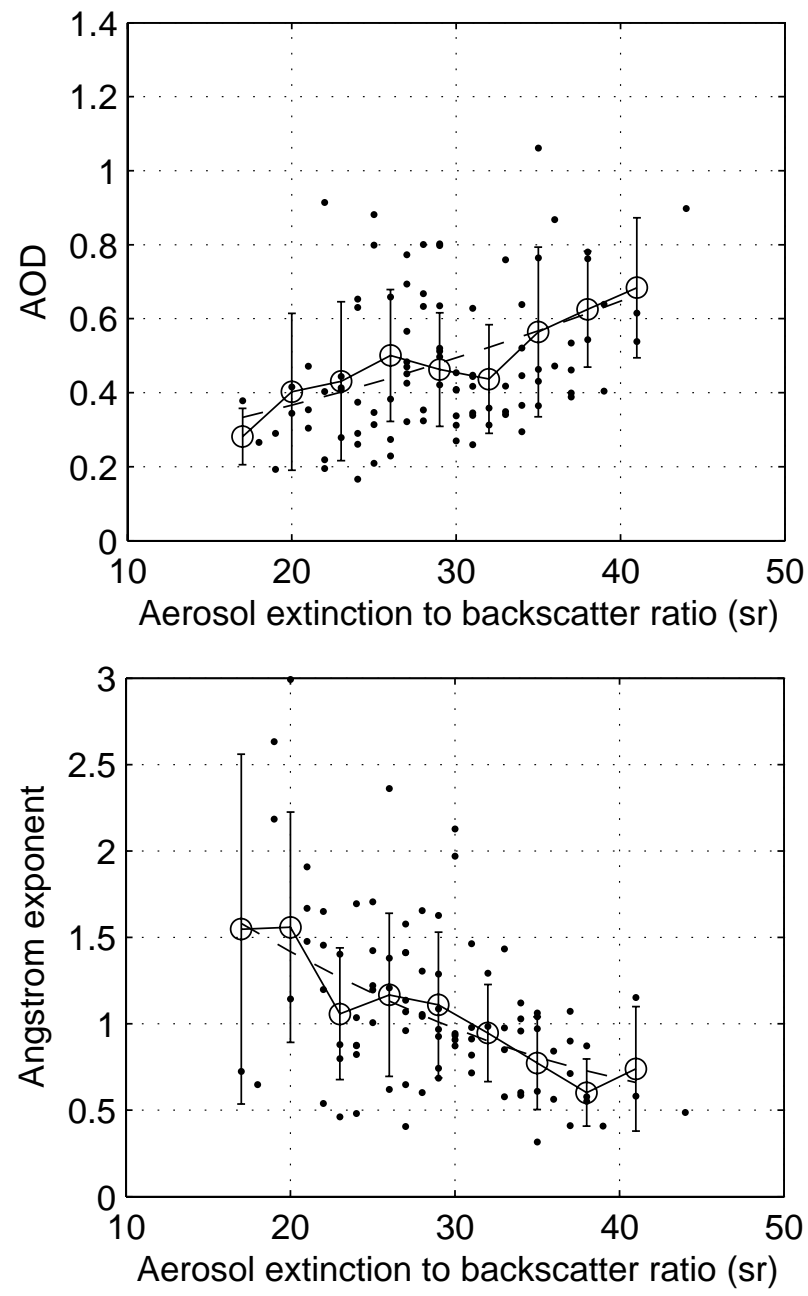

Fig. 9. (a) Scatter plots of LR versus AOD and (b) LR versus Ångström exponent. The circles and error bars represent the corresponding average values and standard deviations, respectively, computed at 9 equally spaced bin of LR. The dashed lines represent fitting curves by using the polynomial in Table 5 .

large particles contribute more under the situation of a heavy haze event. The latter is related to the fact that continental air mass brings not only absorptive industrial and urban aerosols but also dust-like particles from bare ground or remote area, and fine particles consisting mainly of water-soluble materials under clean conditions. In addition, the large LRs can also be explained by deviations between the scattering characteristics of spheres and spheroids as well as due to absorption by the dust particles.

\section{Conclusions}

The aerosol extinction-to-backscatter ratio at $523 \mathrm{~nm}$ from May 2003 to June 2004 has been examined based on the extinction coefficient profile by MPL and the MODIS AOD
Table 5. Parameters of polynomial fits $\left(y=a x^{2}+b x+c\right.$, where $y$ is the AOD or Ångström exponent and $x$ is the LR) and the corresponding correlation coefficients $\left(\mathrm{R}^{2}\right)$ for both cases.

\begin{tabular}{lll}
\hline & AOD vs. LR & Ångström exponent vs. LR \\
\hline $\mathrm{R}^{2}$ & 0.93 & -0.93 \\
$\mathrm{a}$ & -0.00013 & 0.00077 \\
$\mathrm{~b}$ & 0.0625 & -0.0830 \\
$\mathrm{c}$ & 0.1894 & 2.7687 \\
\hline
\end{tabular}

in Hong Kong. Comparisons between the LIDAR-derived aerosol extinction coefficients near the surface and Belfort visibility sensor measured scatter coefficients are conducted. After absorption correction and wavelength correction good agreements between the two parameters with a correlation coefficient of 0.91 and an RMS of $0.07 \mathrm{~km}^{-1}$ are noted, indicating a reasonable LR retrieval over the MPL site. Preliminary analysis indicates that the aerosol extinction-tobackscatter ratio spans the range from $18 \mathrm{sr}$ to $44 \mathrm{sr}$. The average LR is about $29.1 \pm 5.8 \mathrm{sr}$ in this study which is well within the value for oceanic aerosols. Two statistical tests have been employed to check the frequency distribution of the LR, and both tests confirm that the frequency distribution is Gaussian.

Specifically, the temporal distribution of LR is used to link and interpret LR variations with climatic and synoptic background conditions. This study reveals an essential dependence of LR on the Asiatic monsoon which is the dominant circulation feature over the PRD and East Asia. The lower LR value in summer is characteristic of the dominance of oceanic aerosols. In contrast, the larger LR values in spring and winter are associated with the contribution of local and regional industrial pollutants transported by the prevailing northerly and easterly winds over the observation site. Furthermore, there is a strong dependence of LRs on synoptic conditions such as wind speed and wind direction; larger values of LR are found to correspond well with strong easterly and northerly winds and significantly lower LR values are associated with prevailing southerly. In addition, the correlation between LR and AOD together with the anti-correlation between LR and the Angström exponent imply that the LR can be used to link up the macroscopic and microscopic characteristics of aerosols over the PRD region.

Continental and anthropogenic aerosols have a major impact on the LR values during the spring and winter seasons, which play a very important role in the regional aerosol budget. The LR data obtained in this study over Hong Kong provides valuable information for LIDAR retrieved aerosol extinction coefficient and gives an excellent chance to further investigate the vertical distribution of aerosols. Finally, we also note that these data are also very useful as input parameters for exact radiative transfer models (RTM) over southern China. 
Acknowledgements. The MODIS data are provided by the NASA's Earth-Sun System Division, archived and distributed by the Goddard Earth Sciences (GES), Data and Information Services Center (DISC) and Distributed Active Archive Center (DAAC). We would like to acknowledge the Hong Kong University of Science and Technology (HKUST) for providing the LIDAR data for this study. This study is partially supported by the joint research grants from the National Natural Science Foundation of China (NSFC) and Research Grant Council (RGC) of Hong Kong (Grant number: N_HKUST630/04), the grant from NSFC (Grant Number: 90211001, 40575001) and the grant from the National Basic Research Program (also called 973 Program, Grant Number: G1999045700) of China. We are also grateful for the large amounts of valuable comments on the earlier draft published on ACPD provided by two anonymous reviewers and editors of this journal.

Edited by: R. Volkamer

\section{References}

Ackermann, J.: The extinction-to-backscatter ratio of tropospheric aerosols: a numerical study, J. Atmos. Ocean. Tech., 15, 10431050, 1998.

Ackermann, J., Volger, P., and Wiegner, M.: Significance of multiple scattering from tropospheric aerosols for ground-based backscatter, Appl. Opt., 38(24), 5195-5201, 1999.

Anderson, T. L., Covert, D. S., Ahlquist, N. C., Howell, S. G., Clarke, A. D., and McNaughton, C. S.: Variability of aerosol optical properties derived from in situ aircraft measurements during ACE - Asia, J. Geophys. Res., 108(D23), 8647, doi:10.1029/2002JD003247, 2003.

Andreae, M. O. and Crutzen, P. J.: Atmospheric aerosols: Biogeochemical sources and their role in atmospheric chemistry, Science, 276, 1052-1058, 1997.

Ansmann, A., Riebesell, M., Wandinger, U., Weitkamp, C., Voss, E., Lahmann, W., and Michaelis, W.: Combined Raman elasticbackscatter lidar for vertical profiling of moisture, aerosol extinction, backscatter, and lidar ratio, Appl. Phys., B55, 18-28, 1992.

Ansmann, A., Wagner, F., Althausen, D., Muller, D., Herber, A., and Wandinger, U.: European pollution outbreaks during ACE 2: Lofted aerosol plumes observed with Raman lidar at the Portuguese Coast, J. Geophys. Res., 106(D18), 20 725-20733, 2001.

Ansmann, A., Wagner, F., Muller, D., et al.: European pollution outbreaks during ACE 2: Optical particle properties inferred from multiwavelength lidar and star-Sun photometry, J. Geophys. Res., 107(D15), Art. No. 4259, doi:10.1029/2001JD001109, 2002.

Ansmann, A., Engelmann, R., Althausen, D., Wandinger, U., Hu, M., Zhang, Y., and He, Q.: High aerosol load over the Pearl River Delta, China, observed with Raman lidar and Sun photometer, Geophys. Res. Lett., 32(13), doi:10.1029/2005GL023094, 2005.

Balis, D. S., Amiridis, V., Zerefos, C., et al.: Raman lidar and sunphotometric measurements of aerosol optical properties over Thessaloniki, Greece during a biomass burning episode, Atmos. Environ., 37(32), 4529-4538, 2003.

Cao, J. J., Lee, S. C., Ho, K. F., Zhang, X. Y., Zou, S. C., Fung, K., Chow, J. C., and Watson, J. G.: Characteristics of carbonaceous aerosol in Pearl River Delta Region, China during 2001 winter period, Atmos. Environ., 37(11), 1451-1460, 2003.

Cattrall, C., Reagan, J., Thome, K., and Dubovik, O.: Variability of aerosol and spectral lidar and backscatter and extinction ratios of key aerosol types derived from selected Aerosol Robotic Network locations, J. Geophys. Res., 110(D10), Art. No. D10SA11, doi:10.1029/2004JD005124, 2005.

Chang, C. P. and Krishnamurti, T. N.: Monsoon Meteorology. Oxford Monograph on Geology and Geophysics, No. 7, Oxford Univ. Press, New York, 1987.

Charlson, R. J., Schwartz, S. E., Hales, J. M., Cess, R. D., Coakley, J. A., Hansen, J. E., and Hofmann, D. J.: Aerosols and global warming response, Science, 256(5057), 598-599, 1992.

Chazette, P.: The monsoon aerosol extinction properties at Goa during INDOEX as measured with lidar, J. Geophys. Res., 108(D6), doi:10.1029/2002JD002074, 2003.

Chu, D. A., Kaufman, Y. J., Ichoku, C., Remer, L. A., Tanre, D., and Holben, B. N.: Validation of MODIS aerosol optical depth retrieval over land, Geophys. Res. Lett., 29(12), doi:10.1029/2001GL013205, 2002.

Collis, R. T. H. and Russell, P. B.: Lidar measurement of particles and gases by elastic backscattering and differential absorption in Laser Monitoring of the Atmosphere, edited by: Hinkley, E. D., pp. 71-152, Springler-Verlag, New York, 1976.

De Tomasi, F., Blanco, A., and Perrone, M. R.: Raman lidar monitoring of extinction and backscattering of African dust layers and dust characterization, Appl. Opt., 42(9), 1699-1709, 2003.

De Tomasi, F. and Perrone, M. R.: lidar measurements of tropospheric water vapor and aerosol profiles over southeastern Italy, J. Geophys. Res., 108(D9), doi:10.1029/2002JD002781, 2003.

Di Girolamo, P., Ambrico, P. F., Amodeo, A., Boselli, A., Pappalardo, G., and Spinelli, N.: Aerosol observations by lidar in the nocturnal boundary layer, Appl. Opt., 38(21), 4585-4595, 1999.

Dubovik, O., Holben, B. N., Eck, T. F., Smirnov, A., Kaufman, Y. J., King, M. D., Tanre, D., and Slutsker, I.: Variability of absorption and optical properties of key aerosol types observed in worldwide locations, J. Atmos. Sci., 59, 590-608, 2002.

Dulac, F. and Chazette, P.: Airborne study of a multi-layer aerosol structure in the eastern Mediterranean observed with the airborne polarized lidar ALEX during a STAAARTE campaign (7 June 1997), Atmos. Chem. Phys., 3, 1817-1831, 2003, http://www.atmos-chem-phys.net/3/1817/2003/.

Fernald, F. G.: Analysis of atmospheric lidar observations: Some comments, Appl. Opt., 23(5), 652-653, 1984.

Ferrare, R. A., Melfi, S. H., Whiteman, D. N., Evans, K. D., and Leifer, R.: Raman lidar measurements of aerosol extinction and backscattering: 1. Methods and comparisons, J. Geophys. Res., 103(D16), 19663-19672, 1998.

Ferrare, R. A., Turner, D. D., Brasseur, L. H., et al.: Raman lidar measurements of the aerosol extinction-to-backscatter ratio over the Southern Great Plains, J. Geophys. Res., 106(D17), $20333-$ $20347,2001$.

Franke, K., Ansmann, A., Muller, D., Althausen, D., Wagner, F., and Scheele, R.: One-year observations of particle lidar ratio over the tropical Indian Ocean with Raman lidar, Geophys. Res. Lett., 28, 4559-4562, 2001.

Franke, K., Ansmann, A., Muller, D., et al.: Optical properties of the Indo-Asian haze layer over the tropical Indian Ocean, J. Geo- 
phys. Res., 108(D2), Art. No. 4059, doi:10.1029/2002JD002473, 2003.

Grund, C. J. and Eloranta, E. W.: The University of Wisconsin High Spectral Resolution lidar, Opt. Eng., 30, 6-12, 1991.

Intergovernmental Panel on Climate Change (IPCC): Climate Change 2001: The Science of Climate Change, Technical Summary of theWorking Group I Report, Cambridge Univ. Press, New York, 2001.

Kaufman, Y. J., Tanre, D., Remer, L. A., Vermote, E., Chu, A., and Holben, B. N.: Operational remote sensing of tropospheric aerosol over land from EOS Moderate Resolution Imaging Spectroradiometer, J. Geophys. Res., 102, 17 051-17 067, 1997.

Kaufman, Y. J. and Tanre, D.: Algorithm for remote sensing of tropospheric aerosol from MODIS, Algorithm Theoretical Basis Documents (ATBD-MOD-02), 85 pp., 1998.

Klett, J. D.: Lidar inversion with variable backscatter/extinction ratios, Appl. Opt., 24(11), 1638-1643, 1985.

Kok, G. L., Lind, J. A., and Fang, M.: An airborne study of air quality around the Hong Kong territory, J. Geophys. Res., 102, 19043-19057, 1997.

Kovalev, V. A.: Sensitivity of the lidar solution to errors of the aerosol backscatter-to-extinction ratio: Influence of a monotonic change in the aerosol extinction coefficient, Appl. Opt., 34(18), 3457-3462, 1995.

Li, C. C.: Remote sensing of aerosol optical depth with MODIS and its application in the regional environmental air pollution studies, PhD thesis, Peking Univ., Beijing, China, 2002.

Li, C. C., Mao, J. T., Lau, K. H., Chen, J., Yuan, Z., Liu, X., Zhu, A., and Liu, G.: Study on the characteristics of distribution and seasonal variation of aerosol optical depth in eastern China with MODIS products, Chinese Sci. Bull., 48(22), 2488-2495, 2003.

Lohmann, U. and Feichter, J.: Impact of sulphate aerosols on albedo and lifetime of clouds: A sensitivity study with the ECHAM4 GCM, J. Geophys. Res., 102, 13 685-13 700, 1997.

Louie, P. K. K.: Seasonal characteristics and regional transport of PM2.5 in Hong Kong, Atmos. Environ., 39, 1695-1710, 2005.

Maletto, A., McKendry, I. G., and Strawbridge, K. B.: Profiles of particulate matter size distributions using a balloonborne lightweight aerosol spectrometer in the planetary boundary layer, Atmos. Environ., 37, 661-670, 2003.

Mattis, I., Ansmann, A., Muller, D., et al.: Dual-wavelength Raman lidar observations of the extinction-to-backscatter ratio of Saharan dust, Geophys. Res. Lett., 29(9), doi:10.1029/2002GL014721, 2002.

Mattis, I., Ansmann, A., Muller, D., et al.: Multiyear aerosol observations with dual-wavelength Raman lidar in the framework of EARLINET, J. Geophys. Res., 109(D13), Art. No. D13203, doi:10.1029/2004JD004600, 2004.

Muller, D., Franke, K., Wagner, F., et al.: Vertical profiling of optical and physical particle properties over the tropical Indian Ocean with six-wavelength lidar 1 . Seasonal cycle, J. Geophys. Res., 106(D22), 28 567-28 575, 2001a.

Muller, D., Franke, K., Wagner, F., et al.: Vertical profiling of optical and physical particle properties over the tropical Indian Ocean with six-wavelength lidar 2. Case studies, J. Geophys. Res., 106(D22), 28 577-28 595, 2001 b.

Muller, D., Ansmann, A., Wagner, F., et al.: European pollution outbreaks during ACE 2: Microphysical particle properties and single-scattering albedo inferred from multiwavelength li- dar observations, J. Geophys. Res., 107(D15), Art. No. 4248, doi:10.1029/2001JD001110, 2002.

Muller, D., Franke, K., Ansmann, A., et al.: Indo-Asian pollution during INDOEX: Microphysical particle properties and single-scattering albedo inferred from multiwavelength lidar observations, J. Geophys. Res., 108(D19), Art. No. 4600, doi:10.1029/2003JD003538, 2003.

Muller, D., Mattis, I., Ansmann, A., et al.: Closure study on optical and microphysical properties of a mixed urban and Arctic haze air mass observed with Raman lidar and Sun photometer, J. Geophys. Res., 109(D13), Art. No. D13206, doi:10.1029/2003JD004200, 2004.

Muller, D., Mattis, I., Wandinger, U., et al.: Raman lidar observations of aged Siberian and Canadian forest fire smoke in the free troposphere over Germany in 2003: Microphysical particle characterization, J. Geophys. Res., 110(D17), Art. No. D17201, doi:10.1029/2004JD005756, 2005.

Murakami, T.: Winter monsoonal surges over East and Southeast Asia, J. Meteor. Soc. Japan, 57, 133-158, 1979.

Murayama, T., Masonis, S. J., Redemann, J., et al.: An intercomparison of lidar-derived aerosol optical properties with airborne measurements near Tokyo during ACE-Asia, J. Geophys. Res., 108(D23), Art. No. 800, doi:10.1029/2002JD003259, 2003.

NASA: U.S. Standard Atmosphere Supplements, U.S. Govt. Print. Off., Washington, D.C., 1976.

Pappalardo, G., Amodeo, A., Mona, L., et al.: Raman lidar observations of aerosol emitted during the 2002 Etna eruption, Geophys. Res. Lett., 31(5), Art. No. L05120, doi:10.1029/2003GL019073, 2004.

Phadnis, M. J. and Carmichael, G. R.: Numerical investigation of the influence of mineral dust on the tropospheric chemistry of East Asia, J. Atmos. Chem., 36, 285-323, 2000.

Razenkov, I. A., Eloranta, E. W., Hedrick, J. P., and Garcia J. P.: Improvement of the arctic high spectral resolution lidar, Proc. ILRC22, 91-94, 2004.

Remer, L. A., Kaufman, Y. J., Tanre, D., Mattoo, S., Chu, D. A., Martins, J. V., Li, R., Ichoku, C., Levy, R. C., and Kleidman, R. G.: The MODIS Aerosol Algorithm, Products, and Validation, J. Atmos. Sci., 62(4), 947-973, 2005.

Sakai, T., Nagai, T., Nakazato, M., et al.: Ice clouds and Asian dust studied with lidar measurements of particle extinction-tobackscatter ratio, particle depolarization, and water-vapor mixing ratio over Tsukuba, Appl. Opt., 42(36), 7103-7116, 2003.

Salemink, H. W. M., Schotanus, P., and Bergwerff, J. B.: Quantitative lidar at $532 \mathrm{~nm}$ for vertical extinction profiles and the effect of relative humidity, Appl. Phys., 34, 187-189, 1984.

Sasano, Y., Browell, E. V., and Ismail, S.: Error caused by using a constant extinction/backscattering ratio in the lidar solution., Appl. Opt., 24, 3929-3932, 1985.

Sassen, K. and Cho, B. S.: Subvisual-thin cirrus lidar dataset for satellite verification and climatological research, J. Appl. Meteorol., 31, 1275-1285, 1992.

Smirnov, A., Holben, B. N., Kaufman, Y. J., Dubovik, O., Eck, T. F., Slutsker, I., Pietras, C., and Halthore, R. N.: Optical properties of atmospheric aerosol in maritime environments, J. Atmos. Sci., 59, 501-523, 2002.

Twomey, S.: Influence of pollution on the short-wave albedo of clouds, J. Atmos. Sci., 34, 1149-1152, 1977.

Waggoner, A. P., Ahlquist, N. C., and Charlson, R. J.: Measure- 
ment of the aerosol total scatter-backscatter ratio, Appl. Opt., 11, 2886-2889, 1972.

Wandinger, U., Muller, D., Boeckmann, C., Althausen, D., Matthias, V., Boesenberg, J., Weib, B., Fiebig, M., Wendisch, M., Stohl, A., and Ansmann, A.: Optical and physical characterization of biomass burning and industrial pollution aerosols from multiwavelength lidar and aircraft measurements, J. Geophys. Res., 107, doi:10.1029/2000JD000202, 2002.

Welton, E. J., Voss, K. J., Gordon, H. R., Maring, H., Smirnov, A., Holben, B. N., Schmid, B., Livingston, J. M., Russell, P. B., Durkee, P. A., Formenti, P., and Andreae, M. O.: Ground-based lidar measurements of aerosols during ACE-2: lidar description, results, and comparisons with other ground-based and airborne measurements, Tellus 52B, 636-651, 2000.
Welton, E. J., Voss, K. J., Quinn, P. K., Flatau, P., Markowicz, K., Campbell, J., Spinhirne, J. D., Gordon, H. R., and Johnson, J.: Measurements of aerosol vertical profiles and optical properties during INDOEX 1999 using micropulse lidars, J. Geophys. Res., 107(D1), 8019, doi:10.1029/2000JD000038, 2002.

Zuev, V. E.: Laser Beams in the Atmosphere, Plenum Press, New York, p. 504, 1982. 